European Journal of Pragmatism and American Philosophy

VIII-1 | 2016

Dewey's Democracy and Education as a Source of and a Resource for European Educational Theory and Practice

\title{
John Dewey's Legacy and Spanish Pedagogy
}

Bianca Thoilliez

\section{(2) OpenEdition}

\section{Journals}

Electronic version

URL: http://journals.openedition.org/ejpap/450

DOI: $10.4000 /$ ejpap. 450

ISSN: 2036-4091

Publisher

Associazione Pragma

Electronic reference

Bianca Thoilliez, " John Dewey's Legacy and Spanish Pedagogy », European Journal of Pragmatism and American Philosophy [Online], VIII-1 | 2016, Online since 20 July 2016, connection on 01 May 2019.

URL : http://journals.openedition.org/ejpap/450 ; DOI : 10.4000/ejpap.450

This text was automatically generated on 1 May 2019.

\section{c) $(9) \Theta$}

Author retains copyright and grants the European Journal of Pragmatism and American Philosophy right of first publication with the work simultaneously licensed under a Creative Commons AttributionNonCommercial-NoDerivatives 4.0 International License. 


\title{
John Dewey's Legacy and Spanish Pedagogy
}

\author{
Bianca Thoilliez
}

\section{John Dewey's Legacy: Disseminations, Receptions, Interpretations}

1 The public and international dimension of Dewey's works is one of the most salient features of his career. On one hand, the international dimension of Dewey's ideas can be explained by the waves of social and education reforms in the aftermath of the First and Second World Wars in very different latitudes. Dewey's works fit in very well with the spirit behind the new proposals for reforms. Moreover, Dewey himself directly collaborated on spreading his ideas by traveling the world and giving courses in countries such as Japan, China, Mexico, Turkey, and Russia. On the other hand, the public-minded orientation Dewey gave to his work came about by how he conceived the philosopher's job in pragmatic terms as an imminently reconstructive endeavor that should attempt to solve people's everyday problems of his time, i.e., a philosophy that can only be considered as such if it makes a difference on what is happening in the world while also keeping things happening. It places great emphasis on the present and on the active nature of the philosopher's professional undertakings, which therefore breaks away from the tradition and changes its approach. ${ }^{1}$

2 The two above-mentioned considerations of Dewey's work have in turn led to two different lines of research into the breadth of Dewey's works. Those two lines of research are undoubtedly highly topical due to the renewed interest in pragmatism in general and in Dewey in particular. Much has been published in recent decades on Dewey as a person and on his intellectual legacy in the field of education as well as in other areas. Beyond the understandable interest held by Dewey's legacy itself, the sheer intensity of this publishing comeback is nevertheless surprising. Campbell (2010:35-7) offers a number of explanation for why we might be living in a "golden age" of studies on Dewey: (i) Dewey was a visionary, (ii) Dewey is in fashion, and (iii) Dewey and the "Rorty factor." Any 
attempt of my own to affirm which of Campbell's three reasons is the most correct would be foolhardy at best. Furthermore, in any case, all three likely contributed to the "revival" in interest in Dewey. However, in what follows, I will delve further into the first reason of the three: the one regarding the appeal Dewey's educational and philosophical perspective has today.

The history of publications by and about Dewey provides ample evidence of the resurging interest in Dewey in recent years. For example, the first collected bibliography of Dewey was edited by Richard J. Bernstein for Paul Edwards's Encyclopedia of Philosophy in 1967, which consisted of only six references. That same bibliography was later updated in a revised edition by Donald M. Borchert in 2006, with fourteen new references. Campbell himself added eleven more references that appear between 2000 and 2010, to which he says he could have added dozens more. The Dewey story goes on and on largely due to the spread of his works and ideas over the Internet and other technological media. The first of the two contemporary lines of study on Dewey's legacy, as mentioned above, is concerned with detailed and in-depth analysis of the international reception of Dewey's ideas. The starting premise is that the reception processes of theories and discourse on education always involve a degree of reinterpretation, particularly when one searches outside oneself in a particular context to satisfy some particular needs or ends (Schriewer 2004). Indeed, the internationalization of Dewey's work lends itself well to such considerations. Whether it is through more metaphorical statements such as "traveling libraries" or by means of more operative formulations such as "intersections," "articulations," and "transpositions" (see Popkewitz 2005; and Bruno-Jofré et al. 2010) the concern centers on finding out how Dewey's legacy in philosophy and pedagogy was spread and reconstructed in different national and social contexts, what factors intervened in that spread and reconstruction, and how they worked (see also Hickman \& Spadafora 2009; and Tröhler \& Oelkers 2005). The contexts of international reception usually share the circumstance of finding themselves involved in and concerned about taking on democratic educational reforms. Bellmann calls attention to what is meant by "reception" in Dewey's work, since "[it] also corresponds to the story American pragmatism tells about itself" (Bellmann 2004: 170). This concept makes particular sense in an essentially "patchwork" consideration of pragmatism (Margolis 2004), and of which Dewey was well aware. The Deweyan affirmation of the receptive nature that defines American philosophy ${ }^{2}$ may also explain the ease with which his ideas were re-adapted in very different national contexts, like a kind of round-trip journey. In what follows, we shall see more precisely how the study of Dewey's work has been materialized in Spanish pedagogy.

\section{John Dewey in Spanish Pedagogy}

Featured below are two paradigmatic examples of how confusing the reception and study of Dewey's works has been in Spain in two relevant time periods. ${ }^{3}$ The first one is set in the context of the pedagogic renewal and education reform movements at the Institución Libre de Enseñanza in the early 1900s. The second one is contemporary (from 1980 on), where Spanish pedagogy in the new democratic era has undergone a time of expansion with the development of a nationwide network of new public universities and degree programs in the field of education. 


\subsection{Losing Dewey (in Translation)}

5 One of the most interesting ways Dewey's ideas circulated around much of the world in the early 1900s is related to the boom of translations of his works done at different corners of the world. Spain was one of the places where his works gained attention (first and foremost in the field of education) and were therefore translated. Most of the translations were done by faculty members at the Institución Libre de Enseñana, henceforth ILE. The ILE appeared in Spain as a response to what was known as the "second university question." On February 26, 1875, shortly after the restoration of the monarchy under Alfonso XIII, the reinstated Minister of Public Works and Development (under which was the Department of Education) Manuel Orovio sent a memorandum to every university in Spain. In it he called for an archconservative conception of education and a limit to academic freedom. A group of important university professors responded by resigning their professorships and starting up a self-financed alternative university independent from the state government in August 1876: the ILE. Its aim was clear: to develop and modernize science and to foment a physical, moral, and cultural regeneration of the nation. Armed with this 'regenerationist' purpose, the "institutionalists," led by Francisco Giner de los Ríos (Colmenar, Rabazas, \& Ramos 2015), managed to convince people that the main reason for the backwardness of Spanish science was the lack of scientific and cultural contact with Europe and the United States. The ILE was the undeniable protagonist in innovating science and education in Spain in the early 1900s. In fact,

it is hard to find a renewing idea, innovation or improvement to education introduced and disseminated to any degree of success in the late 1800 s and early 1900 s that the Institución was not behind or even played a major role in promoting.

(Viñao 2000: 27)

6 With the advent of the Second Republic (1931-1939), many institutionalists went on to hold positions in different governments, thereby "officializing" many of the ILE's ideas and initiatives. These, however, were cut short during the Spanish Civil War (1936-1939) and later silenced and forgotten during the long years of the Franco dictatorship (1939-1975).

7 There were two institutionalists who paid special attention to the works of John Dewey: Domingo Barnés (Sevilla, 1879 - Mexico DF, 1940) and Lorenzo Luzuriaga (Valdepeñas, 1889 - Buenos Aires, 1959), who were keen on the pedagogical and political lines at the ILE. Both of them defended the "new school," advocated an active pedagogy, and held several positions of responsibility at the Ministries of Public Instruction and socialist organizations (mainly Liga de Educación Política) before and during the time of the Republic (Carda 1996). Especially noteworthy in their academic careers was their work as translators, as a means to disseminate the new pedagogical ideas that were emerging and circulating in the late 19th and early 20th centuries all over the West. We are particularly interested in their translations of Dewey's works because they have the potential to show how some of Dewey's main ideas became lost in translation. Therefore, we will take Barnés's and Luzuriaga's respective versions The School and Society ${ }^{4}$ and Democracy and Education $^{5}$ as paradigmatic examples of the difficulties in grasping Dewey's ideas in the context of Spanish pedagogy. We will do so by focusing on how some key concepts to Deweyan thought were reflected in the Spanish versions of these two books.

8 The most telling example in The School and Society involves the concept of "growth," Table 1 below lists the most significant examples of the texts analyzed. 
Table 1. The School and Society versus La Escuela y la Sociedad

\begin{tabular}{|c|c|}
\hline The School and Society & La Escuela y la Sociedad \\
\hline $\begin{array}{l}\text { Only by being true to the full growth of } \\
\text { all the individuals who make it up, can } \\
\text { society by any chance be true to itself. }\end{array}$ & $\begin{array}{l}\text { Sólo siendo una realidad el pleno } \\
\text { desenvolvimiento de los individuos que la forman } \\
\text { puede la sociedad ser verdad para sí misma. }\end{array}$ \\
\hline $\begin{array}{l}\text { With the growth of the child's mind in } \\
\text { power and knowledge it ceases to be a } \\
\text { pleasant occupation merely, and becomes } \\
\text { more and more a medium, an instrument, } \\
\text { an organ and is thereby transformed. }\end{array}$ & $\begin{array}{l}\text { Con el desenvolvimiento del espíritu del niño, en } \\
\text { cuanto a su poder y conocimiento, cesa de ser una } \\
\text { simple ocupación placentera y se convierte cada } \\
\text { vez más en un medio, en un instrumento y en un } \\
\text { órgano, y de este modo es transformado. }\end{array}$ \\
\hline $\begin{array}{l}\text { The child must be brought into contact } \\
\text { with more grown people and with more } \\
\text { children in order that there may be the } \\
\text { freest and richest social life. Moreover, } \\
\text { the occupations and relationships of the } \\
\text { home environment are not specially } \\
\text { selected for the growth of the child; the } \\
\text { main object is something else, and what } \\
\text { the child can get out of them is incidental. } \\
\text { Hence the need of a school. }\end{array}$ & $\begin{array}{l}\text { El niño debe ponerse en contacto con más gente y } \\
\text { con más niños para que pueda darse la más fresca y } \\
\text { rica vida social. Además, las ocupaciones y las } \\
\text { relaciones que envuelven el hogar no están } \\
\text { especialmente seleccionadas en vista del } \\
\text { desenvolvimiento del niño; el principal objeto } \\
\text { perseguido es otro, y lo que los niños puedan } \\
\text { obtener será puramente incidental. De aquí la } \\
\text { necesidad de la escuela. }\end{array}$ \\
\hline $\begin{array}{l}\text { In this school the life of the child becomes } \\
\text { the all controlling aim. All the media } \\
\text { necessary to further the growth of the } \\
\text { child center there. }\end{array}$ & $\begin{array}{l}\text { En ésta, la vida del niño es la preocupación rectora. } \\
\text { En ella tienen su centro todos los medios necesarios } \\
\text { para el desenvolvimiento del niño. }\end{array}$ \\
\hline $\begin{array}{l}\text { Another instinct of the child is the use of } \\
\text { pencil and paper. All children like to } \\
\text { express themselves through the medium } \\
\text { of form and color. If you simply indulge } \\
\text { this interest by letting the child go on } \\
\text { indefinitely, there is no growth that is } \\
\text { more than accidental. }\end{array}$ & $\begin{array}{l}\text { Otro instinto del niño es el uso del papel y el lápiz. } \\
\text { Todo niño desea expresarse mediante la forma y el } \\
\text { color. Si os limitáis a condescender este interés, } \\
\text { dejando que el niño actúe indefinidamente, no hay } \\
\text { desenvolvimiento que sea más accidental. }\end{array}$ \\
\hline $\begin{array}{l}\text { Now, keeping in mind these fourfold } \\
\text { interests -the interest in conversation or } \\
\text { communication; in inquiry or finding out } \\
\text { things; in making things, or construction; } \\
\text { and in artistic expression we may say they } \\
\text { are the natural resources, the uninvested } \\
\text { capital, upon the exercise of which } \\
\text { depends the active growth of the child. }\end{array}$ & $\begin{array}{l}\text { Ahora bien, recordando estos cuatro intereses -el } \\
\text { interés en la conversación o comunicación, en la } \\
\text { investigación o hallazgo de cosas, en la } \\
\text { construcción o en hacerlas y en la expresión } \\
\text { artística- podemos decir que son los recursos } \\
\text { naturales, el capital un no descubierto, de cuyo } \\
\text { ejercicio depende el desenvolvimiento activo del } \\
\text { niño. }\end{array}$ \\
\hline
\end{tabular}


Unless culture be a superficial polish, a veneering of mahogany over common wood, it surely is this -the growth of the imagination in flexibility, in scope, and in sympathy, till the life which the individual lives is informed with the life of nature and of society. When nature and society can live in the schoolroom, when the forms and tools of learning are subordinated to the substance of experience, then shall there be an opportunity for this identification, and culture shall be the democratic password.

Moreover, if the school is related as a whole to life as a whole, its various aims and ideals culture, discipline, information, utility cease to be variants, for one of which we must select one study and for another. The growth of the child in the direction of social capacity and service, his larger and more vital union with life, becomes the unifying aim; and discipline, culture and information fall into place as phases of this growth.

One thing, then, we wanted to find out is how much can be given a child that is really worth his while to get, in knowledge of the world about him, of the forces in the world, of historical and social growth, and in capacity to express himself in a variety of artistic forms. From the strictly educational side this has been the chief problem of the school.

At the end of three years, then, we are not afraid to say that some of our original questions have secured affirmative answers. The increase of our children from fifteen to almost one hundred, along with a practical doubling of fees, has shown that parents are ready for a form of education that makes individual growth its sole controlling aim.
Al menos que la cultura sea un pulimento superficial, una chapa de caoba sobre madera común, seguramente habrá de ser esto el desenvolvimiento de la imaginación en flexibilidad, alcance y simpatía hasta que la vida que el individuo vive esté informada por la vida de la naturaleza y la sociedad. Cuando la naturaleza y la sociedad pueden vivir en la escuela, cuando las formas y los instrumentos de la cultura están subordinados a la substancia de la experiencia, entonces habrá una oportunidad para esta identificación y la cultura será el pasaporte democrático.

Además, si la escuela está relacionada en su conjunto con la vida como un todo, sus varias e ideales -cultura, disciplina, información, utilidaddejan de ser variantes, para cada uno de los cuales se selecciona un estudio determinado. El desenvolvimiento del niño en la dirección de la capacidad y el servicio social, y su unión más amplia y vital con la vida, se convierte en la aspiración unificadora, y la disciplina, la cultura y la información se colocan en su lugar como fases de este desenvolvimiento.

Nos enorgullecemos de haber señalado cuanto puede proporcionarse al niño de una cosa realmente digna de ser obtenida, del conocimiento del mundo que le rodea, de las fuerzas que actúan en ese mundo, del desenvolvimiento histórico y social y de la capacidad para expresarse en una variedad de formas artísticas. Este ha sido el mayor problema de la escuela, desde el punto de vista estrictamente educativo.

Al cabo de los tres años podemos decir que algunos de nuestros problemas originales han tenido una solución afirmativa. El aumento de nuestros alumnos, desde quince a un centenar, próximamente, unido a un aumento de los honorarios, demuestra que los padres están favorablemente dispuestos para una forma de educación que convierta el desenvolvimiento individual en su única aspiración rectora. 
The everyday work of the school shows that children can live in school as out of it, and yet grow daily in wisdom, kindness, and the spirit of obedience that learning may, even with little children, lay hold upon the substance of truth that nourishes the spirit, and yet the forms of knowledge be observed and cultivated; and that growth may be genuine and thorough, and yet a delight.
La labor diaria de la escuela muestra que el niño puede vivir en ella como fuera de ella $y$ desenvolverse, no obstante, diariamente, en cuanto a sabiduría, bondad y espíritu de obediencia porque la cultura puede, aun tratándose de niños pequeños, cimentarse sobre la substancia de la verdad que nutre el espíritu, observando y cultivando también las formas del conocimiento, y ese desenvolvimiento será perfecto y genuino, constituyendo, verdaderamente, una iluminación.

(TRANS. D. BARNÉS)

Given the many uses of the word "growth" throughout the piece, what made Barnés choose the concept of desenvolvimiento? 'Desenvolvimiento' is clearly closer to the idea of "flourishing" reminiscent of Fröbel's pedagogy than it is to Dewey's "growth." In fact, it seems likely that the influence of Fröbel's work on Spanish pedagogy in the early 20th century may be explained by the "liberties" Barnés took when translating Dewey's ideas, which not only changed the meaning, but also had major theoretical implications from the point of view of education. Study of Barnés's edition clearly shows that he equates the Fröbelian concept of flourishing with the Deweyan concept of growth and development. In his introduction to The education of man, Fröbel made it clear that the purpose of education was to cultivate true humanity, which is none other than the flourishing of the essence in everyone, i.e., of the divine bit that naturally dwells within each individual, his spirit. ${ }^{6}$ The rise of this approach to Barnés's ideas is explicitly acknowledged by him personally. ${ }^{7}$ Amid all this conceptual confusion, Dewey became lost in translation..$^{8}$ This confusion became especially noteworthy when Dewey himself tried to differentiate his discourse from Fröbel's. One of the moments when Dewey makes these differences explicit is in one of the chapters in the second edition of The School and Society, titled "Froebel's Educational Principles." In it, Dewey started assessing some of the positive contributions from Fröbel's pedagogy. ${ }^{10} \mathrm{He}$ therefore begins by acknowledging but then goes on to delve deeper into the critical points that he believes Fröbel's educational principles present. Dewey's criticism focuses on the following aspects of Fröbel's contribution:

i. the role given to playing games in the child development, as a means and not an end in itself, like part of the elements aimed at growth:

There is every evidence that Froebel studied carefully [...] the children's plays [...]

But I do not see the slightest evidence that he supposed that just these plays, and

only these plays had meaning. (MW 1: 83-4)

ii. The symbolism present in Fröbel's work, about which he notes that "many of his statements are cumbrous and far-fetched, living abstract philosophical reasons for matters that may now receive a simple, everyday formulation" (MW 1: 84).

iii. How these two elements, play and symbolism, influence childhood imagination, and how Fröbel presents idealized stimuli that hamper it instead of stimulating it:

The more natural and straightforward these are [the cluster of suggestions, reminiscences, and anticipations that gather about things the child uses], the more definite basis there is for calling up and holding together all the allied suggestions which make his imaginative play really representative. (MW 1: 86) 
iv. The lack of any thematic continuity among classroom activities and everyday life in Fröbel's proposals:

This continuity is often interfered with by the very methods that aim at securing it. From the child's stand point unity lies in the subject-matter - in the present case, in the fact that he is always dealing with one thing: Home life. (MW 1: 88)

v. The methodology to use in planning early childhood education:

Nothing is more absurd than to suppose that there is no middle term between leaving a child to his own unguided fancies and likes or controlling his activities by a formal succession of dictated directions (MW 1: 90).

The second example of the misunderstandings found in Spanish pedagogy regarding Dewey's ideas is found in Luzuriaga's translated version of Democracy and Education. The study of this translation focuses on how two key concepts to Deweyan thought are reflected in the Spanish version. The most telling examples involve the concepts of "growth" and "mind." Table 2 below lists the most significant examples of the texts analyzed. Three main interpretative remarks will follow.

Table 2. Democracy and Education versus Democracia y Educación

\begin{tabular}{|c|c|}
\hline Democracy and Education & Democracia y Eduación \\
\hline $\begin{array}{l}\text { While this "unconscious influence of the } \\
\text { environment" is so subtle and pervasive that } \\
\text { it affects every fiber of character and mind, it } \\
\text { may be worthwhile to specify a few directions } \\
\text { in which its effect is most marked. }\end{array}$ & $\begin{array}{l}\text { Como esta "influencia inconsciente del } \\
\text { ambiente" es tan sutil y penetrante que afecta a } \\
\text { todas las fibras del carácter y el espíritu, puede } \\
\text { valer la pena especificar unas cuantas } \\
\text { direcciones en las que su efecto es más } \\
\text { marcado. }\end{array}$ \\
\hline $\begin{array}{l}\text { We have explicitly added, however, the } \\
\text { recognition of the part played in the joint } \\
\text { activity by the use of things. The philosophy } \\
\text { of learning has been unduly dominated by a } \\
\text { false psychology. It is frequently stated that a } \\
\text { person learns by merely having the qualities } \\
\text { of things impressed upon his mind through } \\
\text { the gateway of the senses. }\end{array}$ & $\begin{array}{l}\text { Sin embargo, hemos añadido explícitamente el } \\
\text { reconocimiento de la parte desempeñada por la } \\
\text { utilización de las cosas en la actividad conjunta. } \\
\text { La filosofía del aprender ha estado } \\
\text { indebidamente dominada por una falsa } \\
\text { psicología. Se ha afirmado con frecuencia que } \\
\text { una persona aprende meramente por tener las } \\
\text { cualidades de las cosas impresas sobre su } \\
\text { espíritu a través de la puerta de los sentidos. }\end{array}$ \\
\hline $\begin{array}{l}\text { The difference between an adjustment to a } \\
\text { physical stimulus and a mental act is that the } \\
\text { latter involves response to a thing in its } \\
\text { meaning; the former does not. A noise may } \\
\text { make me jump without my mind being } \\
\text { implicated. }\end{array}$ & $\begin{array}{l}\text { La diferencia entre una adaptación a un } \\
\text { estímulo físico y un acto mental estriba en que } \\
\text { este último supone la respuesta a una cosa en su } \\
\text { sentido, y el primero no. Un ruido puede } \\
\text { hacerme estremecer sin que intervenga en ello } \\
\text { mi espíritu. }\end{array}$ \\
\hline
\end{tabular}


The conception that growth and progress are just approximations to a final unchanging goal is the last infirmity of the mind in its transition from a static to a dynamic understanding of life. It simulates the style of the latter. It pays the tribute of speaking much of development, process, progress. But all of these operations are conceived to be merely transitional; they lack meaning on their own account. They possess significance only as movements toward something away from what is now going on. Since growth is just a movement toward a completed being, the final ideal is immobile. An abstract and indefinite future is in control with all which that connotes in depreciation of present power and opportunity.

The adult uses his powers to transform his environment, thereby occasioning new stimuli which redirect his powers and keep them developing. Ignoring this fact means arrested development, a passive accommodation. Normal child and normal adult alike, in other words, are engaged in growing. The difference between them is not the difference between growth and no growth, but between the modes of growth appropriate to different conditions. With respect to the development of powers devoted to coping with specific scientific and economic problems we may say the child should be growing in manhood. With respect to sympathetic curiosity, unbiased responsiveness, and openness of mind, we may say that the adult should be growing in childlikeness. One statement is as true as the other.

A mind that is adequately sensitive to the needs and occasions of the present actuality will have the liveliest of motives for interest in the background of the present, and will never have to hunt for a way back because it will never have lost connection.
La concepción de que el crecimiento y el progreso son precisamente aproximaciones a un objetivo invariable es la última crisis del espíritu en su transición desde una interpretación estática de la vida a otra dinámica. Ella simula el estilo de la última. Paga el tributo de hablar mucho de desarrollo, proceso, progreso. Pero todas estas operaciones son concebidas como meramente transitorias; carecen de sentidos por sí mismas. Sólo poseen significación como movimientos hacia algo fuera de lo que ahora está ocurriendo. Puesto que el crecimiento es precisamente un movimiento hacia un ser completo, el ideal final es inmóvil. Domina un futuro abstracto $y$ definido, con todo lo que significa como depreciación de los poderes y oportunidades presentes.

El adulto utiliza sus poderes para transformar su ambiente, ocasionando así nuevos estímulos que dan otra dirección a sus poderes y los mantienen desarrollándose. Ignorar este hecho significa un desarrollo detenido, una acomodación pasiva. En otras palabras, el niño normal y el adulto normal están consagrados por igual a crecer. La diferencia entre ellos no está en crecer o no crecer, sino en los modos de crecimiento apropiados a las diversas condiciones. Con respecto al desarrollo de las energías dedicadas a resolver problemas específicamente científicos y económicos, podemos decir que el niño debe crecer en virilidad. Con respecto a la curiosidad simpatizante, a las reacciones imparciales y a la amplitud de espíritu, podemos decir que el adulto debe crecer en infantilidad. Una afirmación es tan verdadera como la otra.

Un espíritu que sea adecuadamente positivo a las necesidades y ocasiones de la actualidad presente poseerá los motivos más vivos para interesarse por el fondo del presente, y no tendrá nunca que buscar un camino de regreso porque no habrá perdido conexión con él. 
Thus we have completed the circuit and returned to the conceptions of the first portion of this book: such as the biological continuity of human impulses and instincts with natural energies; the dependence of the growth of mind upon participation in conjoint activities having a common purpose; the influence of the physical environment through the uses made of it in the social medium; the necessity of utilization of individual variations in desire and thinking for a progressively developing society; the essential unity of method and subject matter; the intrinsic continuity of ends and means; the recognition of mind as thinking which perceives and tests the meanings of behavior.
Así hemos completado el circuito el circuito y volvemos a las concepciones de la primera parte de esta obra, tales como la continuidad biológica de los impulsos e instintos humanos con las energías naturales; la dependencia del desarrollo del espíritu respecto a la participación en actividades conjuntas que tienen un propósito común; la influencia del ambiente físico mediante el uso que se hace de él en el medio social; la necesidad de utilizar las variaciones individuales en el deseo y el pensamiento para un desarrollo progresivo de la sociedad; la unidad esencial del método y la materia de estudio; la continuidad intrínseca de los fines y los medios; y el reconocimiento del espíritu como pensamiento que percibe y comprueba los significados de la conducta.

(trans. L. Luzuriaga)

11 Our first observation is that Luzuriaga's translation overall is a really bad translation (clearly worse in quality than Barnes's). For a Spanish native speaker with a lowerintermediate competence in English, the original version of Democracy and Education would be more understandable than Luzuriaga's translation. This situation makes the fact even more surprising that it is this particular Spanish version that still being published nowadays.

Our second observation is how in this piece - unlike in The School and Society - "growth" is rightly translated as "crecimiento." How is this possible? Actually, Democracy and Education is the second place where Dewey himself made it clear how far apart his theory was from Fröbel's. Dewey sees the education process as "a continuous process of growth" (MW 9: 59) that, in the Darwinian line of explaining change, does not have an external, ulterior end to itself. However, the Fröbelian conceptualization of growth as development is completely unrelated to this, being conceived as the opposite, as "the unfolding of latent powers towards a defined objective" (Fröbel 1913: 58). The differentiating line that Dewey draws between his philosophical proposal and Fröbel's is very clear despite the latter having some positive aspects here as well. ${ }^{11}$ Dewey's vision of childhood development and growth soundly breaks away, one reason for which was his adherence to evolutionists' claims, his finalistic orientation to that growth. In the translation analyzed above, this idea is lost and is replaced by the idea of "flourishing," which is fundamental to Fröbel's pedagogical perspective and at the core of what Dewey called traditional education. ${ }^{12}$ To Dewey, education is growing and developing: he acknowledges other general functions of education, such as management, control and orientation, ${ }^{13}$ but they are always guided by the attempt to foster more and better growth and development. The context of the work, Democracy and Education, "forced" its audience to make a more careful reading of what Dewey really meant by "growth," since he devoted two full chapters of the book (chapters four and five) to establishing a sharp line between his views and Fröbel's. On this occasion, Dewey refines his philosophy to make it easier 
for the reader to grasp the background of his pedagogic ideas. This made it possible for Luzuriaga to get the right translation this time.

Our third remark is that, although "growth" is rightly translated as "crecimiento," "mind" got translated by Luzuriaga as "espíritu," which is closer to "spirit" than "thought." Once again, this misunderstanding is reminiscent of Fröbel's pedagogy and a consequence of not fully understanding Dewey's philosophical approach. By translating "mind" as "espiritu," it opens up a rift in the theory. While it is true that it may be one of the possible translations of the word, it is only in the context of "mind" as opposed to "matter," as in substance. The option Luzuriaga takes by assuming that Dewey's intended meaning of "mind" is somehow an opposite of a prior matter or substance points to a mistaken interpretation he made of Dewey's work. And yet, it is precisely as a reaction against this type of dichotomies that pragmatism was founded. When Dewey speaks of "mind" he is strictly referring to the human ability to think, rather than the human spiritual quality that defines a person as a rational soul.

Fröbelian mediation made Deweyan concepts sound familiar to Barnés and Luzuriaga's Spanish ears. However, Dewey got lost in translation and as a result, Spanish pedagogy could not fully appreciate the radically different meaning these ideas had in the new approach to philosophy and to understanding education that Dewey's pragmatism entailed.

\subsection{Varieties of Approaches to Dewey}

In this section I present the results of the bibliographic study done by which it is possible to gauge how much attention contemporary Spanish pedagogy pays to Dewey's legacy. To do so, I have selected writings that study Dewey's pedagogical ideas published in Spain as of the year 1980, regardless of the academic affiliation of the author (i.e., national or international) or of the language in which the article was published (whether one of the co-official languages in Spain or some other).$^{14}$ I did not consider any articles on Dewey's philosophy of education published outside Spain (i.e., in foreign-based journals or publishing houses) by authors belonging to Spanish institutions.

As expected, it was found that the purpose of this attention varied from one piece to another. Subsequent analysis made possible to establish the following thematic classifications: (i) Approach 1: works that offer a general overview or introduction to Dewey's thoughts on education, some even accompanied by a short extract of texts by the author; (ii) Approach 2: works that study the reception and influence of Dewey's work in different geographic contexts (especially considering the case of Spain) and their relationship to broader currents in education (such as "progressive pedagogy" or "the new school"); (iii) Approach 3: works that review or reinterpret specific aspects and topics on education, mainly to discuss contemporary pedagogic issues, and in some cases, to compare Dewey's perspective with that of another author or school of thought; (iv) Approach 4: works that propose specific pedagogical practices or analyze existing ones inspired by or in the prism of Dewey's works.

17 In global terms, the subject matter most often discussed in the bibliographic sources found is the third one, with studies that revise and interpret concrete elements of Dewey's work as a way of re-thinking pedagogic questions of contemporary relevance today. This is followed, at $23 \%$, by works that study the reception of Dewey's pedagogical work in the world and its connection to other currents in education at the time, or 
inherited from the concrete tradition where Dewey's new ideas reached. Last come the works that offer a general overview or introduction to his philosophy (12\%) and those that link it to concrete practices in education (10\%). Finally, to relate the subject matter of the writings and the periods in which they were published - 1980s (5 references), ${ }_{15}^{15}$ 1990s (13 references), ${ }^{16}$ 2000s (26 references), ${ }^{17}$ and 2010s (25 references), ${ }^{18}$ - there is a clear rise in interest, albeit modest in comparison to the attention Deweyan studies receive in Italy and other European countries.

With respect to the analysis performed, ${ }^{19}$ some considerations should be made. The first is regarding its form and scope, whereas the second involves the content and approach of the written works in the analysis. Thus, in the first, it should be noted that the list of writings presented here must be read as provisional and under constant revision, since it would be unwise to claim that our analysis includes each and every publication (without exception) of the works on Dewey published in Spain since 1980. Although we can state that we have located many if not most of them, there may still be others we missed. In any case, the nature of the analysis lends itself to periodic updating. In the second point, although the main purpose of this analysis was to quantify the rise in interest in Dewey in contemporary Spanish pedagogy, a global assessment can be made of what this production means. I came up with very few examples in recent years that have made an in-depth study of the possibilities of Dewey's ideas in philosophy of education. This is due to two main reasons. One is related to the nature of Dewey's work regarding the two different "audiences," philosophical and educational, who were attracted to his writings. Actually, a very useful point for understanding how his ideas were disseminated and received, and how they were and still are being interpreted, is that given the fact that Dewey's writings take up subject matters that interest audiences (professional philosophers on one hand, teachers and social reformers on the other) that are usually very removed from each other (and particularly in Spain, very much so), the vast majority of Spanish scholars has tended to read and study the part of Dewey's work that subject-wise interested them the most while ignoring the rest. Although this is understandable to some extent, it is equally true that it commits one of the greatest "errors" Dewey fought against his entire life (in line with the pragmatist tradition he was part of): the separation of theory from practice.

This last consideration lead us to the second reason why Dewey's work has not been taken seriously in Spain: the nature of the field of the theory of education, namely, the rather unique way this area is articulated in this country. Due to the relevance this last argument has in understanding the particular way in which Dewey's work has been studied in Spain, it will be developed in the following and final section of the paper.

\section{Afterword: Addressing Some of Our Problems}

In many of the geographical contexts in which Dewey disseminated his work, the ones on the education side of the fence paid little heed to what Dewey said about philosophy, and vice versa. This situation helps explain several different misinterpretations Dewey's works have been subject to and have been demonstrated in different studies on the international reception of Dewey's ideas (Popkewitz 2005; and Bruno-Jofré \& Schriewer $2009,2012)$. Spain is by no means immune to this problem, as can be seen in the Spanish example given above of how Dewey gets lost, this time, in translation. Our examples are consistent with other works that have shown that Dewey's ideas were not always well 
understood in the early 20th century as a result of the sharp rise that other philosophical currents and some forms of religious thought had on the field of education (Bruno-Jofré \& Jover 2009). The analysis of the production generated around the study of Dewey's legacy in Spain over the last thirty-five years shows that the potential of Dewey's philosophical and educational thought has not been fully explored. Nevertheless, this is consistent with what happened in the past. It is as if the reasons why Dewey was only partially known by scholars and professionals in Spanish education in the ILE circles continued on today in the theory of education in Spain, under new forms of inertia but leading to a similar result in terms of not taking Dewey seriously. As Dewey himself said, we can understand these inertias as habits and customs of thought:

We are always possessed by habits and customs, and this fact signifies that we are always influenced by the inertia and the momentum of forces temporally outgrown but nevertheless still present with us as a part of our being. Human life gets set in patterns, institutional and moral. (LW 11: 36)

21 Even so, these inertias are prone to change: "[C]hange is also with us and demands the constant remaking of old habits and old ways of thinking, desiring and acting" (LW 11: 36). It is noteworthy that only around $25 \%$ of the contemporary references to Dewey's thought in contemporary Spanish pedagogy have Democracy and Education as a relevant reference. Despite the growing interest in Dewey's works since the early 1980s, the main focus of this secondary literature on Dewey has not been on democratic education. This is quite astonishing since in terms of the development of thinking about education for democracy in the 20th century, the figure of John Dewey towers above everyone else. His is the most significant contribution to thinking about education and democracy. This fact has gone unnoticed in most texts on Dewey's ideas that have been published in Spain over the last thirty-five years. And a more detailed revision of how Dewey defined the field of philosophy of education in Democracy and Education would also be extremely useful in solving some of the core problems that the theory of education is facing today in Spain.

One of the biggest contemporary problems facing the theory of education in Spain is that of conjugating the relationship between theory and practice in education and the nature of pedagogical knowledge that such a relationship can generate. The partial (and rather distorted, as we have seen here) reception of Dewey's ideas by Spanish pedagogy is written off by some as a missed opportunity (Colom \& Rincón 2004) for reactivating the theory of education in the context of contemporary Spanish pedagogy. In Spain, the theory of education as an epistemological and disciplinary field is the result of a deliberate effort at a very particular time in history, of a small community of researchers who decided to make a paradigm shift in how to do "pedagogy." ${ }^{20}$ They decided to direct it toward a more technified version. The effort was meant to distance it from "general pedagogy" (heir to the model inaugurated by Herbart and imported into the Spanish university system in the early 20th century), which in these years of transition to democracy was deemed overly speculative and "philosophical" and thus became known as "theory of education." I am well aware of the fact that this is a hasty sketch of events, and it would be complicated to try to sum up in a few lines the core problems that the theory of education is facing today in Spain, but as some recent analyses indicate (Rabazas 2014; Touriñán 2014), they mostly involve three main points: the thematic dispersion combined with an exclusive localist approach (which ignores more than participates in international debates on philosophy and education), the difficulty in defending its status as an autonomous discipline, and the general questioning experienced overall by the more reflexive humanistic dimension of pedagogical studies. 
Thus, while the case of the theory of education in Spain is a historical problem that needs to be analyzed historically, the motives and outcomes of this decision were and are epistemological. As such, I also think the answer comes in the shape of an epistemological proposal, conscious of its inheritance and knowledgeable of the needs and problems of today. As Jaume Sarramona pointed out, "[h]istorical and pragmatic explanations aside, the name change from 'Pedagogy' to 'Theory of Education' has not solved the expectations of its promoters" (Sarramona 2000: 8). Sarramona points to "corporativist" causes to explain how the expectations of what the theory of education should be and their "wish to find a more empirical, less exclusively philosophical underpinning to educational action" (Ibid.) have not been met. However, I believe the problem may be in the shape and direction of that wish by thinking that theory and practice are two substantially contrary things, different and irreconcilable. The theory of education is neither more nor better as a theory of education, it will not generate more or better growth, not in itself as a discipline, not in education as a field of interest, if it is less theory based and more practice based, or less philosophy and more science, or less speculative and more empirical. Perhaps the problem lies in the question itself, and perhaps also in the hope of finding a disciplinary model that normatively closes how supposedly theoretical and practical discourses should be modulated. Perhaps what we need to do is simply to initiate a real conversation in the form of our own reconstruction. A more detailed revision of how Dewey defined the field of philosophy of education in Democracy and Education would also be extremely useful in solving some of the core problems that the theory of education is facing today in Spain. And it is in that sense that Dewey's bizarre reception among Spanish educational theorists, can be interpreted as a missed opportunity for the development of the field itself.

Thus, if we were able to address our problems by taking Dewey's works more seriously, the field of educational theory in Spain would most likely improve in the following ${ }^{21}$ ways: firstly, by understanding his activity as an eminently empirical endeavor that does not propose to go beyond the realm of experience, a realm in which there are myriad paths to explore nonetheless; secondly, by committing to seeking out improvements, and therefore expecting results to be of interest to other philosophers of education but also to society and the learning and teaching community; and thirdly, by acknowledging that the philosophy of education is an intellectual pursuit that works with abstractions, but this does not keep it from remaining perfectly connected to the matters of education. The argument I am advancing here is that the pragmatism that gave Dewey such good results when exploring a philosophy of education that is deeply educational while still being philosophy may also help solve some of the problems felt in the theory of education in Spain. At the same time, this would also lead us to a more integrated reading of Dewey, rather than strictly philosophical or purely pedagogical. Moreover, such integration is fundamental in Dewey, since philosophy to him has a transformative sense with a certain direction. Indeed, this dual transformative-orientative quality of philosophy is what makes it a deeply educational area. ${ }^{22}$ Similarly, the educational perspective is what will help philosophy not make the mistake of believing that the practice of philosophy consists of an exercise of itself, made by and for philosophers (MW 9: 338). In fact, for Dewey, what the people involved in developing the philosophy of education need to do is to work for "the introduction of a new order of conceptions leading to new modes of practice" (LW 13: 3). Therefore, rebuilding the theory of education as per Dewey would lead us to understand his activity as (i) an imminently empirical endeavor that (ii) does not propose transcending the realm of experience, and that, however, (iii) can be 
explored along many different paths, the most characteristic being the conceptual path. It may be well worth our while to try.

\section{BIBLIOGRAPHY}

ANDRÉS P., (2015), “Tendencias pedagógicas y didáctica: 4 visiones en 4 tiempos,” Revista de la SEECI 36, 130-42.

ANGELINI L., \& A. GARCÍA, (2015), "Percepciones sobre la integración de modelos pedagógicos en la formación del profesorado: la simulación y juego y el 'flipped classroom'," Teoría de la Educación: Educación y Cultura en la Sociedad de la Información, 16, 2, 16-30.

AYALA P., (2013), “Justly, Truly, Lovely and Freely. On Thinking How to Teach Art," Artseduca 4, 6-15.

BARNÉS D., (1917), Fuentes para el estudio de la paidología, Madrid, Imp. de la Revista de Arch., Bibl. y Museos.

BARNÉs D., (1926), “La Pedagogía de J. Dewey,” Boletín de la Institución Libre de Enseñanza, L (797), 238-47.

BARREna S., (2015), Pragmatismo y educación: Charles S. Peirce y John Dewey en las aulas, Madrid, Antonio Machado Libros.

BARRoso M. C., (1988), El concepto de experiencia en John Dewey como núcleo de reconstrucción de su teoría educativa, La Laguna, Secretariado de Publicaciones de La Laguna.

BELLMANN J., (2004), "Re-Interpretation in Historiography: John Dewey and the Neo-Humanist Tradition," Studies in Philosophy and Education, 23, 5, 467-88.

BELTRÁN F., (1994), “¿Lee a John Dewey la nueva derecha?,” Cuadernos de Pedagogía 231, 80-6.

BELTRÁN F., (2005), “John Dewey: una democracia vital,” in VV.AA., Pedagogías del siglo XX, Barcelona, CISS Praxis.

BOyDSTON J. A., (1969), John Dewey: A Checklist of Translations, 1900-1967, Carbondale and Edwardsville, Southern Illinois University Press.

BLANCO G., (1981), “Los grandes pedagogos: John Dewey,” Padres y maestros 86, 16-7.

BLAnco R., (1996), “Un clásico del siglo XX: J. Dewey,” Revista de Educación 311, 397-407.

BRONCANO A., (2003), "Pragmatismo y psicología cultural en las escuelas democráticas y las comunidades de aprendizaje," Con-ciencia social: anuario de didáctica de la geografía, la historia y las ciencias sociales $7,142-46$.

BRUNO-JOFRÉ R., (2010), “La educación como tecnología de transformación: análisis comparativo transhistórico de la presencia de Dewey en Iberoamérica a comienzos del siglo XX, del movimiento de educación popular de los años setenta y de la influencia de Freire," Bordón. Revista de pedagogía, 62, 3, 9-19. 
BRUNO-JOFRÉ R., \& G. JOVER, (2009), “Lecturas de la Obra de John Dewey en Intersección con el Catolicismo: Los casos de la Institución Libre de Enseñanza y la Tesis sobre Dewey del Padre Alberto Hurtado, S. J.," Encounters on Education 10, 3-22.

BRUNO-JOFRÉ R., \& J. SCHRIEWER, (eds.), (2009), “Leyendo a John Dewey: procesos de recepción y adopción en diferentes espacios socio-históricos," Encounters on Education 10.

BRUNO-JOFRÉ R., \& J. SCHRIEWER, (2012), The Global Reception of John Dewey's Thought: Multiple Refractions through Time and Space, London, Routledge.

BRUNO-JOFRÉ R., JOHNSTON J. S., JOVER G., \& D. THRÖLER, (2010), Democracy and the Intersection of Religion. The Reading of John Dewey's Understanding of Democracy and Education, Montreal, McGillQueen's Press.

CADRECHA M. Á. (1985), “La educación moral y cívica en John Dewey,” Magister: Revista miscelánea de investigación 3, 203-19.

CADRECHA M. Á. (1990a), “John Dewey: propuesta de un modelo educativo. I. Fundamentos," Aula abierta 55, 61-88.

CADRECHA M. Á. (1990b), "John Dewey: propuesta de un modelo educativo: II. Concepto democrático de la educación," Aula abierta 56, 81-94.

CADRECHA M. Á. (1991). “John Dewey: propuesta de un modelo educativo: III. Valores, situación histórica y conclusión crítica," Aula abierta 57, 43-60.

CAMPBell J., (2010), “John Dewey today,” Pragmatism Today. Journal of the Central-European Pragmatist Forum, 1, 2, 35-7.

CAMPBELL J., (1996), Understanding John Dewey: Nature and Cooperative Intelligence, Chicago, Open Court.

CARBAJAL P., (2013), "Convivencia democrática en las escuelas: apuntes para una reconceptualización," Revista Iberoamericana de Evaluación Educativa, 6, 2, 13-35.

CARDA R. M., (1996), “Domingo Barnés,” in Sáiz M., \& Sáiz D., (eds.), Personajes para una historia de la psicología en España, Madrid, Pirámide.

CARRERAS C., (2015), “John Dewey y la educación democrática," Educació i Historia. Revista d'Historia de l'Educació 25, 21-42.

CARRERAS I PLANAS C., (2003), L'herència deweyana: la "Philosophy for children" de Matthew Lipman i les bases del coneixement, Girona, Documenta Universitaria.

CLAvo M. J., (1993), “El modelo de investigación de J. Dewey y dificultades del naturalismo,"

Eurídice 3, 111-32.

Colmenar C., RABAZAS T., \& S. RAmos, (2015), Francisco Giner de los Ríos y su legado pedagógico, Madrid, La Catarata.

Colom A. J., \& J. C. RINCóN, (2004), “Epistemología neoidealista y fracaso fundacional del saber educativo," Teoría de la Educación. Revista Interuniversitaria 16, 19-48.

CREMADES A., (2008), "El pragmatismo y las competencias en educación musical," Revista Electrónica de LEEME: Lista Electrónica Europea de Música en la Educación, 21.

CREMADES A., (2012), La intervención social en la educación musical: una propuesta didáctica desde el pragmatismo y las competencias, Tesis Doctoral defendida en la Universidad de Sevilla. 
CURTIS M., (2007), “Educando al alma psicológica. Profesorado," Revista de Curriculum y Formación del Profesorado, 11, 3.

CURRIE-KNIGHT K., (2011), “The (Other) Half of Knowledge: John Dewey, Michael Oakeshott, and Parallel Critiques of Rationalism in Education," Bajo Palabra. Revista de Filosofía 6, 63-72.

DE LA FUENTE M. C., (2008), La influencia de la pedagogía progresista de John Dewey en el aula de inglés, Almería, Tutorial Formación.

DEL CASTILLO R., (2014a), “Pobres diablos.: José Gaos, John Dewey y la metafísica made in USA,” Dianoia: anuario de Filosofía, 59, 72, 131-52.

Del CASTILLO R., (2014b), “Pobres diablos.: José Gaos, John Dewey y la metafísica made in USA (segunda parte)," Dianoia: anuario de Filosofía, 59, 73, 113-33.

DEL Pozo M. M., (1996), “John Dewey,” in Ruiz J., (ed.), La Educación en los Tiempos Modernos. Textos y Documentos, Madrid, Editorial ACTAS.

DEWEY J., (1909), “Pragmatism," in Withney D. W., (ed.), Century Dictionary. New Vocabulary Supplement II. Retrieved from [global-language.com/CENTURY].

DEWEY J., (1969-1991), The Collected Works, 1882-1953, edited by Boydston J. A., 37 vols., Carbondale and Edwardsville, IL, Southern Illinois University Press.

DOMÍNGUEZ E., (2002), “El experimentalismo y el cientificismo de Dewey: las teorías y los métodos de la Escuela Nueva," in Colom A. J., (ed.), Teorías e instituciones contemporáneas de la educación, Barcelona, Ariel.

DURAN J., (1993), “The Intersection of Pragmatism and Feminism,” Hypathia, 8, 2, 159-71.

ESCÁMEZ J., (2007), “Las aportaciones de la teoría de la educación," Revista Española de Pedagogía, $65,237,217-36$.

eVANS K. G., (2000), “Reclaiming John Dewey, Democracy, Inquiry, Pragmatism, and Public Management," Administration and Society, 32, 3, 308-28.

FAIRFIELD P., (ed.), (2010), John Dewey and Continental Philosophy, Southern Illinois University Press. FEINBERG W., \& C. A. TORRES, (2014), “Democracia y educación: John Dewey y Paulo Freire," Cuestiones pedagógicas: Revista de ciencias de la educación 23, 29-42.

FERNÁNDEZ M., (2010), “El instrumentalismo de Dewey y la educación en derechos humanos (EDH). Una propuesta pedagógica para abordar la problemática de la violencia escolar a partir de la noción de la experiencia educativa," Antítesis, 3, 6, 795-821.

FERMOSO P., (1991a), “Bibliografía sobre John Dewey: filosofía de la educación,” Teoría de la Educación. Revista Interuniversitaria 3, 165-78.

FERMOSO P., (1991b), “John Dewey,” in VV.AA., Filosofía de la Educación Hoy. Autores: Selección de textos, Madrid, Dykinson.

FRÖBEL F., (1913), La educación del hombre, transl. de Zulueta L., Madrid, Daniel Jorro.

GARCíA F., (2003), El pensamiento pedagógico de John Dewey y su influencia en la pedagogía contemporánea, Tesis Doctoral defendida en la Universidad de Jaén.

GARRISON J., (2006), “The ‘Permanent Deposit' of Hegelian Thought in Dewey's Theory of Inquiry,” Educational Theory, 56, 1, 1-37. 
GONZÁLEZ J., (2001), “John Dewey y la pedagogía progresista,” in Trilla J., (ed.), El legado pedagógico del siglo XX para la escuela del siglo XXI, Barcelona, Graó.

GOoD J. A., (2006), A Search for Unity in Diversity. The Permanent Hegelian Deposit in the Philosophy of John Dewey, Lanham, Lexington Books.

GUICHOT V., (2001), El pensamiento educativo de John Dewey, Tesis Doctoral defendida en la Universidad de Sevilla.

GUICHот V., (2002), "La formación inicial del profesorado en el siglo XXI: reflexiones a partir de la propuesta de John Dewey (1859-1952)," in VV.AA., Reflexiones sobre la práctica psicopedagógica en el siglo XXI, Huelva, Hergué.

GUICHOT V., (2003), Democracia, ciudadanía y educación: una mirada crítica sobre la obra pedagógica de John Dewey, Madrid, Biblioteca Nueva.

GUichot V., (2010), "Bases pedagógicas de la escuela nueva. El progresismo de John Dewey," in Sanchidrián M. C. \& Ruiz J., (eds.), Historia y perspectiva actual de la educación infantil, Barcelona, Graó.

HICKMAN L. A., \& G. SPADAFORA, (eds.), (2009), John Dewey's Educational Philosophy in International Perspective: A New Democracy for the Twenty-First Century, Carbonadale and Edwardsville, Southern Illinois University Press.

JACKSON P. W., (2002), John Dewey and the Philosopher's Task, New York, Columbia University.

JACKSON P. W., (2009), “John Dewey,” in Shook J. R., \& Margolis J., (eds.), A Companion to Pragmatism , Oxford, Blackwell Publishing.

JIMÉNEZ J., (2011), “La dimensión social de la educación en John Dewey y su relación con el Trabajo Social," in Miranda M., (ed.), Política social y trabajo social: desarrollo histórico y debates actuales, Zaragoza, Universidad de Zaragoza.

JIMÉNEZ J. R., (2007), “John Dewey: educar para una ciudadanía democrática,” Kikiriki. Cooperación educativa $85,72-5$.

JOHNSTON J. A., (2008), Regaining Consciousness. Self-Consciousness and Self-Cultivation from 1781Present, Saarbrücken, VDM Verlag Dr. Muller.

JORGE M., (2003), “Visiones de la infancia en el 'child studies' norteamericano: G. Stanley Hall, E. L. Thorndike y John Dewey (entre los siglos XIX y XX)," in Naya L. M., \& Dávila P., (eds.), La infancia en la historia: espacios y representaciones, Guipuzcoa, Erein.

JOVER G., \& A. GARCÍA, (2015), "Relectura de la educación por competencias desde el pragmatismo de John Dewey," Teoría de la Educación: Educación y Cultura en la Sociedad de la Información, 16, 1, 32-43.

JOVER G., \& V. E. GOZÁLVEZ, (2012), "La universidad como espacio público: un análisis a partir de dos debates en torno al pragmatismo," Bordón. Revista de pedagogía, 64, 3, 39-52.

JOVER G., RUIZ M.A., \& B. THoILliEz, (2010), “La obra de John Dewey en su tránsito por España durante el primer tercio del siglo XX: dos ejemplos de recepción editorial," Edetania: estudios y propuestas socio-educativas $37,33-56$.

LARRAURI M., (2012), La educación según John Dewey, Valencia, Tàndem.

LóPEZ J. I., (2009), “El dorado Dewey,” Cuadernos de Pedagogía 395, 78-81. 
MARGolis J., (2004), “The First Pragmatists," in Marsoobian A.T., \& Rider J., (eds.), The Blackwell Guide to American Philosophy, Oxford, Blackwell Publishing.

MENDES L. H., (1982), Evolución darwiniana y educación deweyana, Tesis Doctoral defendida en la Universidad Complutense de Madrid.

MIRANDA M., (2005), Pragmatismo, interaccionismo simbólico y trabajo social. De cómo la caridad y la filantropía se hicieron científicas, Tesis Doctoral defendida en la Universitat Rovira i Virgili.

MIRARD W. R., (1980), “Implications of Dewey for Feminist Theory in Education," Educational Horizons 58, 197-202.

MIRAS N. S., (2013), “Juego, trabajo y arte. Los pragmatistas de Chicago y la construcción de formas sociales de experiencia democrática," BRAC: Barcelona, Research, Art Creation, 1, 2, 153-74.

MOLERo A., (2004), “John Dewey," Infancia: educar de 0 a 6 años 86, 28-31.

MOLERo A., \& M. M. DEL POZo, (eds.), (1994), Antología socio-pedagógica. John Dewey, Madrid, CEPE.

MOLINOS M. C., (1998), "Los hábitos intelectuales / morales y su educación: John Dewey," in

Molinos M. C., Laspalas F. J., \& González M. C., (eds.), Docencia y formación: estudios en honor del profesor José Luis González-Simancas, Navarra, Eunsa.

Molinos M. C., (2002), Concepto y práctica del currículo en John Dewey, Pamplona, Eunsa.

NUBiola J., (2005), “The Reception of Dewey in the Hispanic World," Studies in Philosophy and Education, 24, 6, 437-53.

NUBiola J., \& B. Sierra, (2001), “La recepción de Dewey en España y Latinoamérica," Utopía y Praxis Latinoamericana, 6, 13, 107-19.

OELKERS J., (2000), "Democracy and Education: About the Future of a Problem," Studies in Philosophy and Education, 19, 1-2, 3-19.

OLIVERio S., (2014), “Para una educación en el cosmopolitismo reflexivo," Diálogo Filosófico 88, 27-49.

PAPPAS G. F., (ed.), (2011), Pragmatism in the Americas, Bronx, Fordham University Press.

POPKEWITZ T. S., (2003), “Dewey y Vygotsky: ideas en espacios históricos,” in Popkewitz T. S., Franklin B. M., \& Pereyra M. Á., (eds.), Historia cultural y educación: ensayos críticos sobre conocimiento y escolarización, Granada, Pomares.

POPKEWITZ T. S., (2007), "La historia del currículo: La educación en los Estados Unidos a principios del siglo XX como tesis cultural acerca de lo que es y debe ser el niño," Revista de Curriculum y Formación del Profesorado, 11, 3.

POPKEWITZ T. S., (ed.), (2005), Inventing the Modern Self and John Dewey: Modernities and the Travelling of Pragmatism in Education, New York, Palgrave Macmillan.

RABAZAS T., (ed.), (2014), Origen y desarrollo de la teoría de la educación en España, Madrid, Síntesis. RINCÓN J. C., (2010), "Epistemologia evolucionista i educació en el pensament de John Dewey,” Estudis balearics 96-97, 49-63.

ROMO A. P., (2006), La educación democrática en John Dewey: una propuesta pedagógica de transformación social en México, Tesis Doctoral defendida en la Universidad de Navarra.

RUIz G., (2013), “La teoría de la experiencia de John Dewey: significación histórica y vigencia en el debate teórico contemporáneo," Foro de Educación, 11, 15, 103-24. 
SANTos M., (2011), “Limitaciones de la pedagogía de John Dewey," Bordón. Revista de pedagogía, 63, 3, 121-30.

SARRAMONA J., (2000), Teoría de la Educación. Reflexión y normativa pedagógica, Barcelona, Ariel.

SEOANE J. B., (2009), “Ecos de Dewey: a propósito de la relación entre educación, ciencia y

democracia," Foro de Educación 11, 103-21.

SERRANO J. M., PONS R. M., \& M. G. RUIZ, (2007), “Perspectiva histórica del aprendizaje cooperativo: un largo y tortuoso camino a través de cuatro siglos," Revista Española de Pedagogía, 65, 236, 125-38.

SCHRIEWER, J. (2004), “Multiple Internationalities: The Emergence of a World-Level Ideology and the Persistence of Idiosyncratic World-Views," in Charle C., Schriewer J., \& Wagner P., (eds.), Transnational Intellectual Networks: Forms of Academic Knowledge and the Search for Cultural Identities, Frankfurt \& New York, Verlag, 473-534.

STROMNES A. L., (1991), "Dewey's View on Knowledge and its Educational Implications: Critical Considerations," Revista Española de Pedagogía, 49, 189, 195-218.

THOILLIEz B., (2009), “Educación y crecimiento: la lectura institucionista de la obra de John Dewey desde la pedagogía fröebeliana," in Hernández J. M., (ed.), Influencias alemanas en la educación española e iberoamericana, Salamanca, Globalia Ediciones Anthema.

THOILLIEZ B., (2013), Implicaciones pedagógicas del pragmatismo filosófico americano. Una reconsideración de las aportaciones educativas de Charles S. Peirce, William James y John Dewey, Tesis Doctoral defendida en la Universidad Autónoma de Madrid.

TRÖHLER D., \& J. OELKERS, (eds.), (2005), Pragmatism and Education, Rotterdam, Sense Publishers. TOURIÑÁN J. M., (2014), Dónde está la educación: actividad común interna y elementos estructurales de la intervención, La Coruña, Netbiblo.

TRACHTENBERG T. S., (2010), “Educación, diversidad cultural y participación: una aproximación desde la filosofía de John Dewey," Edetania: estudios y propuestas socio-educativas 37, 69-82.

VIÑAO A., (2000), “Un modelo de reforma educativa: los institutos-escuelas (1918-1936),” BILE 39, 63-88.

VON FEILIZEN C., (2002), “Aprender haciendo: reflexiones sobre la educación y los medios de comunicación," Comunicar. Revista de Medios de Comunicación y Educación 18, 21-6.

WESTBROOK R. B., (1993), “John Dewey (1859-1952),” Perspectivas: Revista trimestral de educación comparada 1-2, 289-305.

ZAMPIERI M., (2011), “Premissas Construtivistas Vivenciadas na Realidade Gerencial," REICE. Revista Iberoamericana sobre Calidad, Eficacia y Cambio en Educación, 9, 1, 103-20.

\section{NOTES}

1. In his piece "The Need for a Recovery in Philosophy" (MW 10: 3-48), originally published in 1917 as part of the collective work Creative Intelligence: Essays in the Pragmatic Attitude, Dewey stated: "Intellectual advance occurs in two ways. At times increase of knowledge is organized about old conceptions, while these are expanded, elaborated and refined, but not seriously revised, much less abandoned. At other times, the increase of knowledge demands qualitative rather than quantitative change; alteration, not addition. Men's minds grow cold to their former 
intellectual concerns; ideas that were burning fade; interests that were urgent seem remote. Men face in another direction; their older perplexities are unreal; considerations passed over as negligible loom up. Former problems may not have been solved, but they no longer press for solution. Philosophy is no exception to the rule. But it is unusually conservative - not, necessarily, in proffering solutions, but in clinging to problems [...]. The association of philosophy with academic teaching has reinforced this intrinsic conservatism [...]. Philosophy when taught inevitably magnifies the history of past thought, and leads professional philosophers to approach their subject matter through its formulation in received systems. It tends, also, to emphasize points upon which men have divided into schools, for these lend themselves to retrospective definition and elaboration [...]. Direct preoccupation with contemporary difficulties is left to literature and politics [...]. I attempt to forward the emancipation of philosophy from too intimate and exclusive attachment to traditional problems. It is not in intent a criticism of various solutions that have been offered, but raises a question as to the genuineness, under the present conditions of science and social life, of the problems" (MW 10: 3-4). References to John Dewey's published works are to the critical edition, The Collected Works of John Dewey, 1882-1953, edited by Boydston J. A., Carbondale and Edwardsville, Southern Illinois University Press, 1967-1991, and published in three series as The Early Works 1882-1899 [EW], The Middle Works 1899-1924 [MW], and The Later Works 1925-1953 [LW].

2. An example of this confirmation is the definition of "pragmatism" Dewey prepared for the Century Dictionary (Dewey 1909: 1050).

3. The paper does not address the broader reception of Dewey's ideas in the Spanish speaking world, mainly in Latin America. See Pappas 2011; and Del Castillo 2014a, 2014 b.

4. As noted in Jover, Ruis, \& Thoilliez 2010, Barnés's translation is a 1910 reprint of the book featuring three conferences given by Dewey in April, 1899 at the laboratory school at the University of Chicago, plus one additional text from a talk Dewey gave at a PTA meeting at the school in February of that same year. For some time it was widely assumed that an alleged 1900 Spanish edition of La escuela y la sociedad had been the first Dewey book in a foreign language. This assumption was based on a reference made in Dewey's Checklist of Translations (Boydson 1969: 49). Today that assumption is known to be mistaken, and although it is still uncertain exactly when the first Spanish translation was published, it seems likely have been between 1915 and 1918 (Nubiola 2005; Nubiola \& Sierra, 2001). The text Barnés uses as a prologue goes with a comment on Dewey's work published by Barnes in his 1917 book Fuentes para el estudio de la paidología (Barnés 1917: 193-200). The end of the prologue, from pages 10 to 15, is repeated again in the article Barnés wrote on Dewey's pedagogy in 1926 in BILE (Barnés 1926).

5. As noted by Bruno-Jofré \& Jover 2009, Democracy and Education was translated by Luzuriaga and published as a series of fascicles by "La Lectura" publishing house between 1926 and 1927.

6. "It should not be assumed that man, the humanity is exteriorized in man, constitutes a complete and already defined manifestation, something fixed and stable, an evolutionary end; rather, a being that is forever changing, progressing and developing, perennially alive, always willing to reach successive degrees of his development and perfection, tending toward ends that rest on the infinite and the eternal" (Fröbel 1913: 20-1).

7. "Development as we conceive of it today must be measured from the point of view of the ends to be achieved. There is no general development, only ends to achieve by the gradual development of the means adapted to them. [...] Just as the body needs air and food, the spirit needs an average culture in order to develop" (Barnés 1917: 75).

8. Jurgen Oelkers (2000) underscores the discontinuity of Dewey's pedagogical proposition with respect to Herbart, Pestalozzi and Fröbel, whose theories he had to reject in order make way for his own. This interpretation, however, has been questioned by Bellmann (2004), who sees in Dewey an example of dialectic between continuity and discontinuity with the German tradition. In more general terms, Dewey scholars today debate the presence of idealistic pedagogy and the 
German notion of Bildung in his pedagogic theory, in what has been called the permanent repository of Hegelian influence on his philosophy. See Garrison 2006; Good 2006; Johnston 2008; and Fairfield 2010.

9. Originally published in 1900 in the series of monographs Elementary School Record and later included in the second edition in 1915 of The School and Society (MW 1: 2-109).

10. "1. That the primary business of school is to train children in co-operative and mutually helpful living; to foster in them the consciousness of mutual interdependence; and to help them practically in making the adjustments that will carry this spirit into overt needs. 2 . That the primary root of all educative activity is in the instinctive, impulsive attitudes and activities of the child, and not in the presentation and application of external material, whether through ideas of others or through the senses; and that, accordingly, numberless spontaneous activities of children [...]. 3. That these individual tendencies and activities are organized and directed through the uses made of them in keeping up the cooperative living already spoken of; taking advantage of them to reproduce on the child's plane the typical doings and occupation of the larger, maturer society into he is finally to go forth" (MW 1: 81-2).

11. "Froebel's recognition of the native capacities of children, his loving attention to them, and his influence in inducing others to study them, represent perhaps the most effective single force in modern educational theory in effecting widespread acknowledgment of the idea of growth. But his formulation of the notion of development and his organization of devices for promoting it were badly hampered by the fact that he conceived development to be unfolding of a readymade latent principle. He failed to see that growing is growth, developing is development, and consequently placed the emphasis upon the completed product. Thus he set up a goal which meant the arrest of growth, and a criterion which is not applicable to immediate guidance of powers, save through translation into abstract and symbolic formulae" (MW 9: 63).

12. One of the places where he offers a description of this traditional model of education is in Experience and Education (LW 13: 3-62): "The main purpose or objective is to prepare the young for future responsibilities and for success in life, by means of acquisition of the organized bodies of information and prepared forms of skill which comprehend the material of instruction. Since the subject-matter as well as standards of proper conduct are handed down from the past, the attitude of pupils must, upon the whole, be one of docility, receptivity, and obedience. Books, especially textbooks, are the chief representatives of the lore and wisdom of the past, while teachers are the organs through which pupils are brought into effective connection with the material. Teachers are the agents through which knowledge and skills are communicated and rules of conduct enforced" (LW 13: 6).

13. Where orientation refers to "the idea of assisting through cooperation the natural capacities of the individuals guided"; control, "conveys rather the notion of an energy brought to bear from without and meeting some resistance from the one controlled"; and lastly, direction is "a more neutral term and suggests the fact that the active tendencies of those directed are led in a certain continuous course, instead of dispersing aimlessly" (MW 9: 28).

14. Bibliographic evidences of Dewey's presence in the Spanish contemporary pedagogy were collected at the Spanish National Library Catalogue, BBDOC CSIC database, REBIUN database, Dialnet database, TESEO database. Although the vast majority of references were originally published in Spanish, all contributions titles are presented in English for better understanding.

15. See Peñalver 1989; Barroso 1988; Cadrecha 1985; Mendes 1982; and Blanco 1981.

16. See Molinos 1998; Blanco 1996; Del Pozo 1996; Beltrán 1994; Molero \& Del Pozo 1994; Clavo 1993; Westbrook 1993; Cadrecha 1991; Fermoso 1991a; Fermoso 1991b; Stromnes 1991; Cadrecha 1990a; and Cadrecha 1990 b.

17. See López 2009; Seoane 2009; Thoilliez 2009; Cremades 2008; De la Fuente 2008; Curtis 2007; Jiménez 2007; Popkewitk 2007; Serrano, Pons \& Ruiz 2007; Romo 2006; Beltrán 2005; Miranda 2005; Colom \& Rincón 2004; Molero 2004; Broncano 2003; Carreras 2003; García 2003; Guichot 
2003; Jorge 2003; Popkewitz 2003; Domínguez 2002; Guichot 2002; Molinos 2002; Von Feilizen 2002; González 2001; and Guichot 2001.

18. See Andrés 2015; Angelini \& García-Carbonell 2015; Barrena 2015; Carreras 2015; Jover \& García 2015; Feinberg \& Torres 2014; Oliverio 2014; Ayala 2013; Carbajal 2013; Miras 2013; Ruiz 2013; Thoilliez 2013; Cremades 2012; Jover \& Gozálvez 2012; Larrauri 2012; Currie-Knight 2011; Jiménez 2011; Santos 2011; Zampieri 2011; Bruno-Jofré 2010; Fernández 2010; Guichot 2010; Jover, Ruiz \& Thoilliez 2010; Rincón 2010; and Trachtenberg 2010.

19. Some of the results of this bibliographic study (up to the year 2012) were integrated in the specialized database that the Centro de Estudios Dewey in España (CEDE), affiliated with the Center for Dewey Studies of the Southern Illinois University Carbondale, is generating in coordination with several Spanish researchers in the field of education, with slightly different criteria than those followed herein. The CEDE, headed by Professors Ramón de Castillo and Julio Seoane, was inaugurated in October 2012 and is affiliated with the Franklin Institute at the Universidad de Alcalá de Henares.

20. One of the most accurate accounts of this decision is told by Escámez, who also took part in it: "For two days in the autumn of 1982, in the charming old building of the University of Murcia, on the Calle de la Merced, 1, in a meeting room in the Vice Chancellor's offices, the following university professors met: Ricardo Marín (General Pedagogy at the University of Valencia), Alejandro Sanvisens (General Pedagogy at Barcelona), Gonzalo Vázquez (General Pedagogy at the Complutense), José Antonio Ibáñez-Martín (Philosophy of Education at the Complutense), José María Quintana (Social Pedagogy at the UNED), José Luis Castillejo (Empirical Introduction to Education Sciences at Valencia), Antonio J. Colom (General Pegagogy at Mallorca), Joaquín García Carrasco (General Pedagogy at Salamanca), Juan Escámez (General Pedagogy at Murcia) and Jaime Sarramona (General Pedagogy at the Autónoma de Barcelona). [...] Despite the many differences in their highest academic degree or doctorate and their achievements in professorships under different denominations, these professors, and no others, met in Murcia to share certain concerns and sound out the possibility of starting new directions in the teaching and research of their disciplines. Their concerns were over the naming of the professorships, the suitability of whether or not to intensify the professional exchanges among the attendees, who together comprised the entirety of professors in these disciplines at Spanish universities, the urgency of bringing new language in to the writings on pedagogy more in line with developments in the biological, social and historical sciences of the 20th century, and the need to adapt research and course offerings to the new political and social dynamics of Spain's transition to democracy. The ensuing heated debate led to two basic majority agreements: the first was to adopt the name of the Theory of Education to replace General Pedagogy, and the other was to hold a yearly work meeting similar to the one that day, to take care of the points of concern. As mentioned, the agreements were majority decisions based on heated debate that logically satisfied most but displeased a few" (Escámez 2007: 219-20).

21. And here I will follow Philip Jackson's reading of Dewey (2002: 59-70).

22. "Whenever philosophy has been taken seriously, it has always been assumed that it signified achieving a wisdom which would influence the conduct of life" (MW 9: 334). 


\section{ABSTRACTS}

Perhaps one of the most characteristic aspects of Dewey's career is that the extent and variety of his work, not to mention his own longevity and his restlessly inquisitive personality, pose a problem to any systematic study of his legacy. At the same time, this "problem" represents the hallmark of his work. Furthermore, Dewey's works and opinions were propagated and spread in many different formats across many different countries, which makes it only more problematic to study his works, their spread and influence. The first part of this article will present a framework for carrying out a contemporary study on the works of John Dewey, with special attention to the current comeback in interest in them in studies on education. The second part of the article will look into the situation of John Dewey's legacy in Spanish pedagogy at two fundamental moments in history: the first in the context of the Institución Libre de Enseñanza, the school that led the attempts to modernize education in Spain in the early 1900s. The second moment will focus on studying how the current renewed interest in Dewey has affected contemporary pedagogy in Spain. The article will end by reflecting on what a more integrated reading of Dewey's pedagogical and philosophical ideas could bring to the theory of education made in Spain.

\section{AUTHOR}

\section{BIANCA THOILLIEZ}

Universidad Autónoma de Madrid

bianca.thoilliez[at]uam.es 